\title{
ABOUT POSSIBILITIES OF BETTER PREPARATION OF FUTURE TEACHERS
}

\section{[O MOZNOSTIACH ZLEPSENIA PRIPRAVY BUDUCICH UCITELOV]}

\author{
Erich Petlak
}

\section{DOI: 10.18355/PG.2015.4.2.190-196}

\begin{abstract}
Educational improvement in our schools also needs to increase quality of teacher education. The author says that in teacher education are still some deficits. These deficits need to be solved by precise linking of theoretical and practical teacher education. Students, future teachers, have rich theoretical knowledge. It's a pity that theoretical knowledge sometimes do not correspond with educational reality. Another problem is also that what students study, they have no opportunity to prove or see it in practice. There is a need to pay attention to create correct interaction to students.
\end{abstract}

\section{Key words}

teacher education, new subjects creation, connecting theory with praxis, preference of theory, school reality, didactic materialism, humanistic orientation of learning process, diagnostics through dialogue, selfreflective model of preparation

\section{Anotácia}

Autor sa v príspevku zaoberá otázkami prípravy budúcich učitel’ov. Zamýšl'a sa nad tým, čí ich súčasná príprava je optimálna. Na základe výsledkov monitorovaní výsledkov práce škôl konštatuje, že je potrebné skutočne dôsledne sa zamýšl'at' nad budúcnost'ou výchovno-vzdelávacej praxe v našich školách, a to aj preto, že dnešné deti sú celkom iné ako deti pred pár rokmi. Poukazuje na rôznorodost' prístupov v príprave budúcich učitel'ov, súčasne však naznačuje možnosti zlepšenia jestvujúceho stavu. Vedúcou ideou príspevku je sústredenie pozornosti na takú prípravu, v ktorej sa pozornost' kladie na formovanie skutočného vzt’ahu ku škole, $\mathrm{k}$ žiakom a vôbec k vzdelávacej realite.

\section{Kl'účové slová}

príprava učitel'ov, kreovanie nových predmetov, spájanie teórie s praxou, preferovanie teórie, školská realita, didaktický materializmus, humanistická orientácia vyučovania, diagnostika dialógom, sebareflexívny model prípravy

Vzhl'adom na to, že v ostatnom období sa čoraz častejšie hovorí o vzdelávaní a príprave vysokoškolákov na prácu, je vhodné pripomenút' niektoré aspekty prípravy budúcich učitel'ov. Vychádzam z toho, že medzi činnost'ou a prácou vysokoškolského učitel'a a študentom - budúcim 
učitel'om je vel'mi úzky vzt'ah, a preto sa v tomto príspevku zamýšl’am nad niektorými súvisiacimi otázkami.

V ostatných rokoch si častejšie kladieme otázky o tom aká je naša škola, aké sú jej výsledky, ako pracujú učitelia, ako sú pripravovaní budúci učitelia na svoju profesiu a pod. Podnetom pre tieto úvahy sú nie práve najlichotivejšie zistenia monitorovaní vedomostnej úrovne našich žiakov. Školám a učitel'om je vytýkané, že vo výchovno-vzdelávacom procese nie sú využívané tvorivé metódy a formy práce. Na viaceré pozitívne, žial', aj negatívne javy upozorn̆uje vo svojej publikácii M. Beňo. V súvislosti $\mathrm{s}$ týmito otázkami sa $\mathrm{v}$ tomto príspevku zamýšl'am nad niektorými aspektmi prípravy budúcich učitel'ov. Vychádzam z toho, že od prípravy budúcej generácie učitel'ov budú $v$ rozhodujúcej miere závisiet' výsledky učebnej činnosti žiakov a úspešnost' nášho školstva.

Nedá mi, aby som hned' v úvode nepripomenul zistenia I. Tureka, ktorý upozorňuje na značné rozdiely v príprave učitel'ov na jednotlivých učitel'ských fakultách z hl'adiska pedagogicko-psychologických predmetov. Pripomína výskum, ktorý bol uskutočnený v rokoch 1992 - 1998 v Českej, Slovenskej a Pol'skej republike a okrem iného potvrdil, že: absolventi učitel'ských fakúlt majú nedostatočný profesný výcvik, majú nedostatočnú spôsobilost' vychovávat' žiakov, nie sú pripravení na roly triednych učitel'ov..., vzdelávanie učitel'ov je stále príliš verbálne, vzdialené od reálnych problémov pedagogickej praxe. Podl'a I. Tureka príprava učitel'ov na Slovensku nemá celoštátnu koncepciu, koordináciu ani kontrolu, je príliš liberálna, rozdielna a roztrieštená (Turek, 2001: 17 - 18).

Od uverejnenia týchto myšlienok uplynulo viac rokov, a tak sa vnucuje otázka: Či a čo sa zmenilo v príprave budúcich učitel'ov v ostatných rokoch? Ak mám vyjadrit' vlastný názor, potom považujem za potrebné uviest', že v ostatných rokoch sme v pedagogicko-psychologickej príprave učitel'ov vel'mi nepokročili. Podstatou mojich úvah sú d'alej uvedené myšlienky, ku ktorým predostieram, že vychádzajú z reality ako ju vnímam, sú zovšeobecnením pohl'adov nielen mojich, ale aj viacerých kolegov, ba aj pohl'adov študentov viacerých učitel'ských fakúlt.

Ak I. Turek konštatoval a poukázal na istú nejednotnost' $\mathrm{v}$ učebných plánoch (z čoho môže plynút' rozdielna úroveň absolventov učitel'stva v príprave na prácu so žiakmi), aj dnes môžeme konštatovat', že v tejto difúznosti zachovávame isté „status quo.“ Rozdielnost' v učebných plánoch, tvorivost' a nápaditost' pri výbere predmetov a ich zostavovaní dnes obhajujeme a zdôrazňujeme autonómiou fakúlt a demokratickými prvkami či zásadami a možnost’ami riadenia. To akceptujem. Na druhej strane si kladiem otázky, či by sa takáto autonómia a demokracia nemohla uplatnit' aj prostredníctvom vzájomne koordinovanej spolupráce viacerých fakúlt alebo katedier. Uvedomujem si vážnost' myšlienky, a preto len v krátkosti dodám: Stačí si prelistovat' a porovnat' učebné plány fakúlt pripravujúcich učitel'ov a zistíme čomu všetkému učíme, ale aj neučíme študentov. V istej snahe byt' „moderní“ opúšt’ame aj niektoré klasické pedagogické predmety a kreujeme nové. 
Realita novosti je niekedy len v zmene názvu predmetu, pričom obsah sa zásadne ani nemení, niekedy oná novost' spočíva $\mathrm{v}$ „nájdení názvu a potom v následnom hl'adaní nového „moderného“ obsahu. Aj viaceré pedagogicko-psychologické pojmy nahrádzame novými, a tak namiesto systému motivačných metód hovoríme o stimulovaní žiakov do učenia, prácu škôl, učitel'ov a žiakov prestávame hodnotit', ale ju diagnostikujeme, evalvujeme, manažujeme, zo škôl sa nám vytráca učitel' a žiak, ktorého nahrádza edukátor a edukant a pod. Táto modernizácia nezasahuje len pedagogiku, ale má širší záber, napr. Katedry hudobnej výchovy premenúvame na Katedry hudby, ba zaznamenal som aj premenu Katedry pedagogiky na Katedru pedagogických štúdií. Skutočne chcem zdôraznit', že nemám nič proti týmto zmenám, akceptujem ich, no súčasne si kladiem otázky: Kol'ko je, resp. kol'ko dávame skutočne inovatívneho do obsahu týchto nových pojmov? Meníme nimi výraznejšie myslenie budúcich učitel'ov a aj učitel'ov v praxi, a teda aj prax v našich školách? K týmto myšlienkam ma primälo i štúdium publikácie W. Brezinku, ktorý analyzuje vzt’ahy medzi očakávaním a dosiahnutým v pedagogike, ale aj otázky nadmerného rozširovania oblasti jej záujmov a prílišnú špecializácia. Vel'mi vážne je konštatovanie W. Brezinku píše: „Z dôvodu nedostatku porozumenia ciel'ov a hlavných otázok pedagogiky jej záujem sa stal tak vel'ký, že ich nemožno súvislo vedecky rozpracovat'. Zaznamenáva sa stagnácia a regresia $\mathrm{v}$ hlavných oblastiach a na periférii vyrástli dva tucty špecializovaných pedagogík a disciplín pseudošpeciálnych, ktoré nie sú spojené s pojmovo-teoretickým kánonom základnej pedagogickej vedy. Máme rad pedagogík ,pedagogika náboženstva“, pedagogika športu“, „,pedagogika vol’ného času“, ,pedagogika médií““ a pod.““ (Brezinka, 2005: 157).

Myslím si, že ten kto reálne hodnotí súčasnost' v našich základných a stredných školách musí priznat', jemne povedané, isté rezervy. Učitelia temer zhodne konštatujú, že čoraz viacej žiakov sa učí len s malým záujmom, že s ich výchovou si temer nevedia poradit', o časti z nich sa vyjadrujú ako o drzých, arogantných, rastie šikanovanie medzi žiakmi a pod. Predpokladám, že situácia sa zásadnejšie nezmení ani v najbližších rokoch. Samozrejme vyššie uvedené neduhy nemožno pripisovat' len práci škôl a učitel'ov. Svoj podiel má aj samotná spoločnost'. No na druhej strane si kladiem otázky, či sa podarí v budúcnosti zlepšit' súčasný stav, či pripravujeme budúcich učitel’ov na čoraz náročnejšiu vzdelávaciu a výchovnú prácu v našich školách. Nie som o tom presvedčený, pretože v príprave učitel'ov sme sa v ostatných rokoch zamerali predovšetkým na kvantitatívnu stránku, na nárast počtu predmetov, ich obsahu a rozsahu, na úkor pedagogicko-psychologickej a aj metodickej prípravy, lepšie povedané na úkor vytvárania, ba priam pestovania a kultivovania vzt'ahu ku škole, $\mathrm{k}$ jej životu $\mathrm{k}$ žiakom, $\mathrm{k}$ rodičom, $\mathrm{k}$ prostrediu. K uvedeným myšlienkam ma vedú viaceré skutočnosti, z ktorých uvediem iba niektoré.

Stačí si prelistovat' len zopár „Informačných listov predmetov“, ktoré vypracúvajú katedry a zistíme značné rozdielnosti. Obsah predmetov v týchto listoch závisí od toho, ktorú „,vedeckú autoritu“, alebo ktorú „vedeckú školu“ zastáva autor - autori Informačného listu. A tak sme 
svedkami toho, že kým na jednej fakulte - katedre sa napr. podstata didaktiky vníma ako predmet vedúci k pochopeniu toho čo je obsah vzdelávania, ako ho učitel' môže modifikovat', ako si ho prostredníctvom metód, foriem, zásad žiaci osvojujú, ako sú v tomto procese motivovaní a hodnotení, kde didaktika je sprostredkúvaná ako predmet výrazne sa inovujúci atd'., na inej fakulte - katedre sa dôraz kladie na rôzne didaktické teórie, ktoré k nám prenikajú, resp. sú ovplyvnené západnou pedagogikou. Avšak chýba prepojenie s našou školou, našou realitou, našou školskou praxou. Kým na jednej fakulte sa dôraz kladie aj na históriu pedagogiky (volitel'ne aj na regionálnu históriu) a jej predstavitel'ov v minulých storočiach, na inej fakulte sa história vôbec neučí alebo sa dôraz kladie predovšetkým na novodobú históriu. Nuž a takto by som mohol vymenúvat' predmet za predmetom. Ak som vyššie spomenul istú orientáciu na západnú pedagogiku a jej rôzne teórie, skutočne to nemyslím ako negatívum. Skôr mi ide o to, že viaceré z týchto teórií ostávajú pre študenta skutočne len v oblasti teórie, pretože nemá možnost' ich vidiet', aplikovat' a hodnotit' ich v praxi. Príklad: Celé hodiny (prednášky a semináre) trávime nad alternatívnymi koncepciami vyučovanie. Aj ked' to vyznie nelichotivo ostávame v rovine teórií, pretože študent nemá dostatok možností vidiet' a v praxi si vyskúšat' využitie jednotlivých koncepcií. Bud'me úprimní a nebojme sa povedat', že aj pedagóg, ktorý o tomto prednáša zväčša pozná mnohé koncepcie len a len z publikácií, pretože alternatívne koncepcie výučby sú $v$ našich školách viac v rovine želaní a predstáv ako skutočnej dôslednej realizácie. Nuž a študent sa učí novému, progresívnemu, inovatívnemu nie v praxi, ale teoreticky. A to už desiatky rokov voláme po „cvičných“, „fakultných“, nech sa nazvú akokol’vek, školách, v ktorých by študent videl a azda si aj vyskúšal aspoň čo-to inovatívne, v ktorých by si skúšal a overoval niečo nové, niečo čo sa naučil, namiesto toho ako je to prevažne v súčasnosti, že vo svojej praxi počas štúdia, ale aj v praxi už učitel'a „kopíruje to ako bol sám vzdelávaný“.

$\mathrm{Na}$ Slovensku máme vel'a katedier a vel'a učitel'ov, naozaj odborníkov odboru istého zamerania. Lenže, každá katedra, každý učitel' (alebo skupina učitel'ov príslušnej katedry) vypracúvajú svoj „Informačný list“", no a každý si do neho vnáša to svoje, to čo ho má odlíšit' od iného, to čo má dokladovat' jeho špecifickost', odbornost' a inovatívnost'. Pýtam sa, a nielen sám seba, či by nebolo vhodnejšie ak by niekol'kí renomovaní odborníci príslušného predmetu vypracovali napr. $60 \%$ záväzného učiva a $40 \%$ nech si dotvorí každý učitel' a každá katedra obsah podl'a svojich výskumných zameraní, podl'a požiadaviek študentov, podl'a požiadaviek regiónu a pod. Nevidím dôvod prečo by sme sa nemohli uberat' takýmto smerom aj vo vysokoškolskom štúdiu, ked' projekt Milénium toto predpokladá vo vzt’ahu k ZŠ a SŠ a ked' sme sa všetci stotožnili s touto ideou.

Samozrejme významnou je aj procesuálna stránka prípravy učitel'ov. Uvedomujem si, že nasledujúcou poznámkou si popudím voči sebe rad kolegov z viacerých fakúlt a katedier, niektorých predovšetkým tým, že poznámka sa ich netýka. Ostatné roky evidujem, že na našich fakultách či katedrách sa hojne zaužívalo písomné skúšanie a preverovanie vedomostí 
študentov, a to aj v tých predmetoch, v ktorých by mal byt' dominujúci a rozhodujúci, pre formovanie študenta ako budúceho učitel'a, dialóg so študentom. Nie som proti priebežným testom, proti testom a písomkám ako kontrole priebežného štúdia, ani proti testom ako splnenie istého minima pre ústnu skúšku a pod. Prečo som proti rôznym testom a písomným previerkam? Z desiatok možných príkladov ako didaktik uvediem: Nie je pre mňa podstatné či študent vymenuje 5 alebo 13 funkcií vyučovacej metódy, nie je podstatné či vymenuje 3 alebo 8 funkcií, ktoré sa spájajú s hodnotením žiaka atd'. Podstatné je či funkciám rozumie, ako ich vie dotvárat', no najmä ako ich vníma v širších pedagogicko-psychologických a metodických súvislostiach. Aj výskumné metódy môže študent vymenovat' všetky, ba aj zaradit' ich podl'a kritérí tej alebo onej publikácie (a bude hodnotený v teste stupňom A). Ale je toto naozaj podstatné? Nie je podstatnejšie to, aby študent preukázal napr. v modelovej situácii ako by pracoval výskumnou metódou, ako by ju využil, ako by využitím výskumnej metódy pomohol žiakovi a pod? Vel'a rokov sa hovorí a volá napr. po inej organizácii štátnej skúšky, po tom, aby táto skúška nebola prezentovaním a hodnotením pamät'ového učenia, ale dôkazom toho, že študent dokáže vyriešit' istú modelovú situáciu, v ktorej by mal syntetizovat' a vaplikácii na prax preukázat' svoje vedomosti, napr. z pedagogiky, psychológie, z metodiky predmetu. Všetci však vieme, že realita je zväčša iná, zatial' je len málo škôl, resp. katedier, v ktorých by bol dominantný práve tento prístup. Študent si na štátnej skúške „vytiahne“ niekol'ko otázok, odpovie ich - podl'a hodnotenia komisie uspeje, prípadne neuspeje. S istým uspokojením však zaznamenávam, že v danej oblasti sa situácia, síce pomaly, ale predsa, začína menit' v tom zmysle ako som naznačil. Týmto chcem zdôraznit' a vyjadrit', že aj procesuálnou stránkou výučby, a teda aj skúšaním máme ubudúcich učitel'ov formovat' skutočné postoje ku škole a žiakom. Ak som spomenul postoje ku škole a k žiakom, žiada sa mi uviest' to čo sa začína častejšie spomínat'. Doktorandské štúdium ako tretí stupeň vysokoškolského vzdelávania má stúpajúcu tendenciu. To je potešitel'né, to je výchova budúcich odborníkov. Čoraz častejšie sa začína hovorit' o tom, že čast' študentov je prijímaná na doktorandské štúdium hned' po skončení štúdia, bez praxe v škole. Myslím si, že fakulty a katedry sa týmto musia zaoberat' a zostavit' také plány doktorandského štúdia, ktoré zabezpečia „nielen štúdium kníh, ale aj štúdium žiakov a pedagogicko-didaktickej reality priamo v školách.“ Bez docenenia uvedeného sa môže stat', že o pár rokov budú na katedrách pôsobit' pedagógovia, psychológovia a didaktici predmetov, ktorí školu a žiakov poznajú len zo skúmaní, ktoré robili počas kvalifikačného rastu. K celkovej príprave študenta na budúce povolanie má výrazne pomáhat' aj pedagogická prax študenta. V minulosti bola mimoriadne významnou súčastou štúdia, bola mimoriadne doceňovaná vedením fakúlt a aj metodikmi katedier. Netvrdím, že dnes je okrajovou záležitost'ou, ale rozhodne sa $\mathrm{k}$ nej nestaviame tak ako by sa patrilo a ako je potrebné. V porovnaní s minulost'ou je jej venovaný menší priestor aj $\mathrm{V}$ časovej dotácii prípravy, čo je však podstatnejšie nemá ten status, tú vážnost' a dôležitost', ktorá jej patrí. V minulosti sa študent počas štúdia 
a prostredníctvom praxe učil skutočne žit' so školou, „nasával ducha školy“, pretože okrem hospitácií a odučených hodín sa podiel'al na dozore počas prestávok, počas štúdia sa zúčastnil aspoň niekol'kých pedagogických rád (aby spoznával čím žije škola, ako rieši svoje pedagogicko-didaktické, výchovné a aj ostatné organizačné oblasti), zúčastnil sa aspoň jedného dvoch združená rodičov, počas štúdia aspoň rok viedol vtedy aktuálny pioniersky oddiel alebo iný záujmový krúžok, podiel'al sa príprave násteniek a celkovej výzdobe triedy. Kým teda, prozaicky povedané, počas celého štúdia skutočne a doslovne „nasával ducha školy“, formoval si postoje a vzt'ah k budúcej profesii a pod., dnešná pedagogická prax je viac menej ,preletom“ cez školu, medzi žiakmi a medzi kolektívom učitel’ov. Nedostatok praxe môže byt' tiež jednou z príčin toho, že vel'a mladých učitel'ov po roku dvoch opúšt'a svoju profesiu. Niektorí sa ani netaja, že prežili ,šok z reality“, na ktorú neboli pripravení.

V súvislosti s procesuálnou stránkou a v neposlednom rade aj s pedagogickou praxou prípravy budúcich učitel'ov môžeme hovorit' o viacerých prístupoch.

Životaschopným, ešte aj v súčasnosti, je prístup, ktorý predpokladá, že študent učitel'stva si počas štúdia musí osvojit' množstvo pedagogickopsychologických a iných odborných a metodických vedomostí, musí si osvojit' obsah predmetov, ktoré bude vyučovat'. Vyučovací proces je mu sprostredkúvaný ako proces, ktorý má svoje zákonitosti. V tomto duchu je vedená aj jeho pedagogická prax. Metodikom alebo učitel’om má „naprogramované“ ako bude učit', ktoré metódy bude využívat' a pod. Iste netreba vysvetl'ovat', že takáto príprava je nevhodná, pretože kladie dôraz na jednostranný didaktický materializmus a nepodporuje tvorivost' študenta, budúceho učitel'a.

Iný prístup spočíva tiež v položení dôrazu na množstvo vedomostí, no pedagogická prax je liberálnejšia, viac priestoru je ponechané na vlastnú tvorivost' študenta, ktorý sa učí, často aj cestou chýb a omylov, a tak si vlastne začína sám pod vedením učitel'ov postupne formovat' prvky svojho štýlu výučby, čo samozrejme trvá aj viac rokov.

V ostatných rokoch je u nás značná orientáciu na humanistickú orientáciu vyučovania, ktorá ovplyvňuje aj prípravu budúcich učitel'ov a aj ich pedagogickú prax. Možno povedat', že vzhl'adom na rôzne prístupy (filozofické a psychologické) nemá táto orientácia vymedzené presné a pevné hranice. Tak ako vo vyučovaní všeobecne aj v príprave učitel'ov sa ponecháva istá vol'nost', proces výučby je procesom ,hl'adania sa ako budúceho učitel'a“, procesom odkrývania osobitého, špecifického. Táto orientácia umožňuje istú modifikáciu, resp. automodifikáciu zaužívaného, pričom sa zdôrazňuje autonómia učitel'a, resp. budúceho učitel'a.

Posledným modelom, o ktorom sa zmienim je model reflexívnej resp. sebareflexívnej prípravy, včítane pedagogickej praxe. V ostatných rokoch sa mu vo svete začína venovat' zvýšená pozornost', pretože najmä v pedagogickej praxi sa študent už počas štúdia stáva „scénaristom“ svojej profesie. Takáto realizácia prípravy a praxe by mala byt' dominujúca v príprave budúcich učitel'ov. Namiesto dlhších úvah a opisov uvediem len 
otázky na zamyslenie sa: Poskytuje súčasná príprava možnosti takejto reflexívnej prípravy? Sú študenti vedení k sebareflexivnej príprave alebo predovšetkým k získavaniu vedomostí? Pravda, pre takúto prípravu by bolo potrebné preniest' viac výučby zo seminárnych miestností do tried škôl.

Predpokladám, že čast' čitatel'ov sa s uvedenými názormi stotožní, čast' bude oponovat' a bude mat' naporúdzi dostatok svojich argumentov a dostatok svojich zdôvodnení o tom ako významne a zásadne sa zmenila príprava budúcich učitel'ov. O tom, že sa zmenila nepochybujem ani ja. Inou otázkou je do akej miery sa zmenila v prospech školstva, či skutočne napĺn̆a profil absolventa budúceho učitel'a a budúcej školy a či by nemohla byt' lepšia. Či mnohé z toho čím je charakterizovaná nová, moderná škola prinášajú absolventi do praxe škôl. Zdá sa, že nie. Toho čo im je počas prípravy prízvukované ako ,alfa a omega“ dnešnej školy, napr. tvorivé metódy vyučovania, žiak ako subjekt vyučovania, motivujúce aspekty hodnotenia, význam interakčných vzt’ahov vo výučbe, potreba rôznorodých alternatívnych metód a foriem práce a pod., je v našich školách stále ako šafránu. Pojem prízvukované som neuviedol náhodou, pretože som presvedčený, že mnohé je študentom skutočne len prízvukované, avšak bez možnosti vyskúšania si v reálnej praxi.

Sumarizáciu týchto, ale aj d’alších aspektov zastávam stanovisko, že súčasná príprava učitel'ov je zameraná predovšetkým na kvantitu vedomostí, ale málo na prežívanie učitel'stva ako profesie, na skutočné vytváranie vzt’ahu k žiakom a mládeži, ku škole, k rodičom.

Na záver chcem zdôraznit', že ním nesledujem žiadnu kritiku a vonkoncom nie znevažovanie práce stoviek pedagógov našich fakúlt a katedier. Ide mi skutočne o istú reflexiu súčasnej prípravy budúcich učitel'ov, o ktorej som presvedčený, že by ju bolo možné výraznejšie inovovat' predovšetkým v pedagogicko-psychologickej a metodickej oblasti. Ak som uviedol inovovanie nemám na mysli d'alšie pridávanie predmetov, ale predovšetkým inovovanie v tom, aby si terajší študenti - budúci učitelia vytvárali skutočný vzt'ah k det'om a ku škole. Ten sme v ostatných rokoch v príprave dost' podcenili.

\section{Bibliography}

BENO, M. a kol. 2004. Regionalne skolstvo v SR: analyticko-prognosticke studie. Bratislava: UIPS. ISBN 807098-388-4.

BREZINKA, W. 2005. Wychowanie a pedagogika w dobie przemian kulturowych. Krakow : Wydawnictwo VAM. ISBN 83-7318-411-2.

TUREK, I. 2001. Navrh koncepcie vzdelavania ucitelov v SR. In: Forum pedagogiky. K problematike koncepcie rozvoja vychovy a vzdelavania v SR a v zahranici. Bratislava: MPC. ISBN 80-8052-119-0.

prof. PhDr. Erich Petlák, CSc.

Technological Institute in Dubnica nad Váhom

Sládkovičova 533/20

01841 Dubnica nad Váhom

Slovakia

petlak@dti.sk 